\title{
Can Flexible Exchange Rates Insulate the Impact of Foreign Monetary Shocks?: The Case of Monopolistic Competition
}

\author{
Hui-Kuan Tseng ${ }^{*}$ \\ University of North Carolina
}

\begin{abstract}
In a two-country model of monopolistic competition where PPP holds at aggregate price levels, this paper examines whether market imperfections alone can fail flexible exchange rates to insulate aggregate output from foreign monetary shocks. It finds that the possibility of insulation hinges on whether monopolists can freely adjust their individual prices to optimum If monopolists keep rigid their individual prices, these shocks will destabilize domestic aggregate output; and the greater the degree of monopoly power, the larger the output fluctuations. The study conveys an implication for recent menu-costs models that price adjustment costs not only can cause price stickiness and non-neutrality of money, as they have shown but can fail flexible rate to achieve insulation as well.
\end{abstract}

The fundamental argument for flexible exchange rates is that they would allow countries autonomy with respect to their use of monetary, fiscal and other policy instruments, consistent with the maintenance of whatever degree of freedom in international transactions they choose to allow their citizens, by automatically ensuring the preservation of external equilibrium.

- H.G. Johnson [1972, pp. 199]

* Correspondence Address: Department of Economics, University of North Carolina, Charlotte, NC 28223, U.S.A.; The author would like to thank two anonymous referees for valuable comments.

D1995 - Institute for International Economics, Sejong Institution. All rights reserved. 


\section{Introduction}

Flexible exchange rates had been widely thought to insulate an economy from foreign disturbances, thereby providing national autonomy in macroeconomic policy issues. Such view was shared by several notable economists 〈Friedman [1953], Meade [1955] and Johnson [1972]). Since the collapse of the Bretton Woods fixed-rate system in 1973, however, our recent experience with flexible rates has clearly run counter to the positive view above. Flexible rates have not only exhibited large fluctuations particularly in 1980s, as opposed to their proponents' belief 〈e.g. Friedman [1955]), but also complicated adjustment problems facing national economies. It appears that flexible rates have failed to achieve national autonomy.

Indeed, several past studies 〈Artus and Young [1979], Mussa [1979], Dornbusch [1983] and Marston [1982, 1985] have shown that flexible rates generally do not even insulate an economy from foreign monetary disturbances. It is because even a foreign shock may transmit its effect on domestic aggregate output through the foreign-price channel, the foreign-output channel, and/or the foreign-interest-rate channel. Thus, insulation or national autonomy is achieved only in special cases. Marston [1982] shows that domestic output can be insulated from a foreign monetary shock if the foreign country has full wage indexation. Such insulation can also be achieved if the law of one price (i.e. domestic and foreign goods are perfect substitutes) is combined with full wage indexation in the home country (Marston [1985]). ${ }^{1}$

The paper is to reexamine the question of whether domestic aggregate output can be insulated from foreign monetary shocks under a flexible-rate system. In contrast to the past studies noted above, this study introduces imperfect competition into the goods market and leaves wages determined in a perfectly competitive market without wage contract and indexation. The new research direction is motivated by recently developed menu-costs models 〈Akerlof and Yellen [1985], Mankiw [1985], Blanchard and Kiyotaki

1. For another example of insulation, see Saidi [1980], where aggregate output is influenced by an intertemporal substitution effect rather than a wage contract lag as seen in Marston [1982, 1985]. 
[1987] and Rotemberg [1987]). Their work shifts the source of Keynesian nominal rigidity from the labor market to the goods market. More importantly, they show that price rigidity, due to price adjustment costs (or socalled menu-costs), can be an equilibrium consistent with agents' optimization behavior. Thus, monetary disturbances can cause the fluctuations of aggregate output and employment in their models without relying on agents' "misperception" as in New-Classical economies 〈Lucas [1973] > or on sticky money wage as in traditional Keynesian economies. Can such macroeconomic fluctuations be transmitted to other national economies under flexible rates? It remains unanswered by the recent menu-costs models. The present paper represents an initial work on addressing this issue.

Shutting off the channel for international capital movements, the study proceeds in a two-large-economies model, where each firm produces an imperfect substitute and is engaged in monopolistic competition and where the condition of purchasing power parity (PPP) holds at aggregate price levels. The absence of capital flows between countries allows us to focus on the role of imperfect competition in the goods market, while making analysis tractable. In contrast to the literature based on perfect competition, the study captures a new channel whereby the flexible exchange rate may or may not achieve insulation when foreign monetary disturbances are present. As the study will show later, whether insulation can occur hinges on the interaction between the price of a domestic product relative to domestic aggregate price and the worldwide real money balances. The main findings of this study are summarized below:

1. When monopolists can freely adjust their prices to optimum, classical results obtain in the world economy; i.e. monetary disturbances only change nominal variables proportionally, hence leaving unchanged relative prices and worldwide real money balances, and hence keeping aggregate output and employment fixed at the classical (full information) equilibrium in each national economy. In addition, such insulation is seen to be independent of country size and the degree of monopoly power as well.

2. When monopolists, subject to price adjustment costs, fail to adjust their prices to optimum, a foreign monetary shock can alter both worldwide real money balances and domestic relative price (i.e. the price of a domestic product relative to domestic aggregate price). For example, when monopo- 
lists keep rigid their individual prices, decreased foreign money supply can reduce worldwide real balances, while raising domestic relative price because the resulting home-currency depreciation inflates domestic aggregate price. It is seen that the negative real-balances effect always outweighs the positive relative-price effect, thereby causing worldwide reductions in aggregate output and employment. Further, the greater the degree of monopoly power (and/or the larger the size of the foreign country), the larger the negative impact on the domestic economy.

These results imply that monopolistic competition alone cannot fail the flexible exchange rate to achieve insulation from foreign monetary disturbances. But if monopolists choose not to adjust their prices (due to price adjustment costs as stressed by recent menu-costs models), the domestic economy cannot be insulated from these disturbances. Insulation can be restored in the latter case with individual price rigidities only when monopolistic competition is reduced to perfect competition in the goods market or the foreign economy degenerates into a small economy.

The rest of this paper is organized as follows. Section II outlines the twocountry model with a representative consumer and many monopolists. Section III finds the equilibrium levels of macroeconomic variables on microfoundation. Section IV examines the impact of a foreign monetary shock for two cases, where price adjustments are free and where price adjustments are costly. In Section V, concluding remarks and promising extensions are given.

\section{The Two-Country Model of Monopolistic Competition}

The model contains two countries, the home country and the foreign country. Each country has a representative consumer and many firms. Labor is the only production factor supplied by consumers in a competitive labor market. Yet, as a price-setter under monopolistic competition, each firm owns market power and produces a differentiated product. The model shuts off the channel for international capital movements. This model simplification enables us to focus on the question of whether market imperfections alone can influence flexible exchange rates to insulate the home country from foreign monetary shocks. Because the two countries are symmet- 
ric in preference and technologies, the home country is taken for most model specification below. Throughout the paper, foreign variables are referred to as those with an asterisk $\left(^{\star}\right)$ and home variables as those without.

\section{A. Consumers}

The representative consumer's welfare is derived from aggregate consumption and leisure. The home country's welfare function is given $b^{2}$

$$
U(C, L)=C-L^{\beta}
$$

where

$$
C=\left(n+n^{*}\right)\left(\frac{1}{n+n^{*}}\left[\sum_{i=1}^{n} c_{i}^{\frac{\sigma-1}{\sigma}}+\sum_{j=1}^{n^{*}} c_{j}^{\frac{\sigma-1}{\sigma}}\right]\right)^{\frac{\sigma}{\sigma-1}}
$$

The first term in $U(\cdot), C$, is a consumption index measuring the level of aggregate consumption. $c_{i}$ 's and $c_{j}^{\prime}$ 's in lower case are home consumption of product $i(=1, \ldots, n)$ and $j\left(=1, \ldots, n^{*}\right)$, respectively. Products $i$ 's $(j$ 's $)$ are produced at home (abroad) with $n\left(n^{*}\right)$ denoting the number of home (foreign) product varieties. The parameter $\sigma$ represents the elasticity of substitution between goods in consumption, reflecting the degree of monopoly power or product differentiation; ${ }^{3}$ this parameter is assumed greater than one, ensuring the existence of an equilibrium. The second term in $U(\cdot), L$, determines disutility from work. $L$ is the level of aggregate employment. The parameter $\beta$ is assumed greater than one, implying increasing marginal disutility of labor.

The home country's aggregate price level is given by the price index:

2. The welfare function (1) is borrowed from Mankiw [1985] and Blanchard and Kiyotaki [1987]. Yet, due to openness, this function is distinct from theirs by incorporating foreign goods into the consumer's consumption basket.

3. In fact, as $\sigma$ approaches infinity, all goods become homogenous (or monopolistic competition is reduced to perfect competition) and the consumption index is simply:

$$
\sum_{i=1}^{n} c_{i}+\sum_{j=1}^{n^{*}} c_{j}
$$




$$
P=\left[\frac{1}{n+n^{*}}\left(\sum_{i=1}^{n} p_{i}^{1-\sigma}+\sum_{j=1}^{n^{*}}\left(e p_{j}^{*}\right)^{1-\sigma}\right)\right]^{\frac{1}{1-\sigma}}
$$

where $p_{i}$ is the price of product $i$ (in home currency), $p_{j}^{*}$ is the price of product $j$ (in foreign currency), and $e$ is the exchange rate or the home-currency price of the foreign currency. As implied by (3), a depreciation of the home currency (i.e. the rise of $e$ ) raises the price index of the home country, given all individual prices unchanged.

The home consumer's holdings of domestic nominal money stock $M^{D}$ is simply determined by the level of aggregate consumption multiplied by the level of aggregate price: ${ }^{4}$

$$
M^{D}=P \cdot C
$$

Equilibrium in the domestic money market requires the equality of nominal money demand $\left(M^{D}\right)$ and nominal money supply $\left(M^{s}\right)$ :

$$
M^{D}=M^{S}=M
$$

Because of (4) and (5), the home consumer maximizes (1) subject to the liquidity constraint:

$$
\sum_{i=1}^{n} p_{i} c_{i}+\sum_{j=1}^{n^{*}} e p_{j}^{*} c_{j}=M
$$

where the consumer's aggregate nominal expenditure is restricted to the available nominal money stock $(M)$. The liquidity constraint therefore provides a channel whereby monetary authorities may influence the world economy. From utility maximization, the home country's demand functions for individual products are given by: ${ }^{5}$

$$
c_{i}=\frac{1}{n+n^{*}}\left(\frac{p_{i}}{P}\right)^{-\sigma}\left(\frac{M}{P}\right), \quad i=1,2, \ldots, n
$$

4. From (3), it is implicitly assumed that money only serves as a medium of exchange rather than a store of value. In addition, it is assumed that domestic consumers do not hold foreign currency. Indeed, the latter is the natural result of the assumed absence of international capital movements here in the paper. 


$$
c_{j}=\frac{1}{n+n^{*}}\left(\frac{e p_{j}^{*}}{P}\right)^{-\sigma}\left(\frac{M}{P}\right), \quad j=1,2, \ldots, n^{*}
$$

Symmetry between countries allows us to write the foreign country's demand functions:

$$
\begin{aligned}
c_{i}^{*} & =\frac{1}{n+n^{*}}\left(\frac{p_{i} / e}{P^{*}}\right)^{-\sigma}\left(\frac{M^{*}}{P^{*}}\right), \quad i=1,2, \ldots, n \\
c_{j}^{*} & =\frac{1}{n+n^{*}}\left(\frac{p_{j}^{*}}{P^{*}}\right)^{-\sigma}\left(\frac{M^{*}}{P^{*}}\right), \quad j=1,2, \ldots, n^{*}
\end{aligned}
$$

where the foreign price index is defined as:

$$
P^{*}=\left[\frac{1}{n+n^{*}}\left(\sum_{i=1}^{n}\left(p_{i} / e\right)^{1-\sigma}+\sum_{j=1}^{n^{*}} p_{j}^{* 1-\sigma}\right)\right]^{\frac{1}{1-\sigma}}
$$

Comparing (3a) and ( $3 \mathrm{~b})$, one can find that both countries compute their price indices in the same manner and that international price discrimination is absent. ${ }^{6}$ Thus, as implied by (3a) and ( $3 b$ ), the condition of PPP (purchasing power parity) holds at aggregate price levels:

$$
P=e P^{*}
$$

With (7), (8) and (9), the world demands for good $i\left(=c_{i}+c_{i}^{*}\right)$ and for $\operatorname{good} j\left(=c_{j}+c_{j}^{*}\right)$ can be expressed respectively by:

$$
\begin{aligned}
& c_{i}+c_{i}^{*}=\frac{1}{n+n^{*}}\left(\frac{p_{i}}{P}\right)^{-\sigma}\left(\frac{M}{P}+\frac{e M^{*}}{P}\right) \\
& c_{j}+c_{j}^{*}=\frac{1}{n+n^{*}}\left(\frac{p_{j}^{*}}{P^{*}}\right)^{-\sigma}\left(\frac{M}{P}+\frac{e M^{*}}{P}\right)
\end{aligned}
$$

5. Certainly, the other choice variable $L$ is determined by equating the marginal utility of aggregate consumption $(C)$ to the marginal disutility of labor $(L)$. Later, Section III will address this question.

6. That is, monopolists regard their home and foreign markets as an integrated market. If otherwise home and foreign markets are segmented, "pricing to market" (i.e. price discrimination between home and foreign markets) will be present. 
Clearly, the world demand for any individual product increases as worldwide real money balances $\left(M / P+e M^{*} / P\right)$ rise, while decreasing as an individual price relative to aggregate price $\left(p_{i} / P\right.$ or $\left.p_{j}^{*} / P^{*}\right)$ rise.

\section{B. Firms}

All firms, domestic or foreign, have the same, linear technology:

$$
\begin{array}{ll}
x_{i}=\ell_{i}, & i=1,2, \ldots, n \\
x_{j}^{*}=\ell_{j}^{*}, & j=1,2, \ldots, n^{*}
\end{array}
$$

where it is implied that the output of a home (foreign) firm, $x\left(x^{*}\right)$, is simply equal to the input of home (foreign) labor, $\ell\left(\ell^{*}\right)$. All firms are engaged in monopolistic competition. Facing a downward-sloping demand curve characterized by (10) or (11), each firm takes as given all other individual prices (or the price indices $P$ and $P^{*}$ ), the competitive nominal wages ( $W$ and $W^{*}$ ) and the exchange rate $(e)$. The linear technologies (12) and (13) imply a constant marginal production cost equal to $W$ for home firms and equal to $W^{*}$ for foreign firms. For simplicity, there exist no fixed costs for the production of goods. Thus, each monopolist sets its optimal price according to the price rules:

$$
\begin{array}{ll}
p_{i}=\left(\frac{\sigma}{\sigma-1}\right) W, & i=1,2, \ldots, n \\
\dot{p}_{j}^{*}=\left(\frac{\sigma}{\sigma-1}\right) W, & j=1,2, \ldots, n
\end{array}
$$

Thus, with a common nominal wage in each country, individual prices are equalized over all home and foreign products, respectively; i.e., $p_{i}=p_{1}=\ldots=$ $p_{n}$ and $p_{j}^{*}=p_{1}^{*}=\ldots=p_{n^{*}}^{*}$. Hereafter, $p_{i}$ is taken as the representative price of individual home goods and $p_{j}^{*}$ as the representative price of individual foreign goods.

\section{Equilibrium and Macroeconomic Variables}

In the model, general equilibrium requires that the three markets for money, goods and labor clear jointly in each country. The money-market 
equilibrium condition has been given by (5). The equilibrium conditions for home and foreign goods are given respectively by $x_{i}=c_{i}+c_{i}^{*}$ and $x_{j}^{*}=c_{j}+c_{j}^{*}$. Using these equilibrium conditions and price equalization, along with (10) and (11), the home and foreign countries' real GDPs, $Y$ and $Y$, are given by:?

$$
\begin{aligned}
& Y=\frac{n}{n+n^{*}}\left(\frac{p_{i}}{P}\right)^{1-\sigma}\left(\frac{M}{P}+\frac{e M^{*}}{P}\right) \\
& Y^{*}=\frac{n^{*}}{n+n^{*}}\left(\frac{p_{j}^{*}}{P}\right)^{1-\sigma}\left(\frac{M}{P}+\frac{e M^{*}}{P}\right)
\end{aligned}
$$

Perfect competition is assumed in the labor market. In each country, nominal wage is perfectly flexible to equate labor demand to labor supply. In terms of (10), (12) and (16), the home country's equilibrium employment level of labor $L=\Sigma \ell_{i}=\Sigma x_{i}$ is given by:

$$
L=Y
$$

at the market-clearing real wage, ${ }^{8}$

$$
\frac{W}{P}=\beta Y^{\beta-1}
$$

Correspondingly, the foreign country's equilibrium employment level $L^{*}=\Sigma \ell_{j}^{*}=\Sigma x_{j}^{*}$ and equilibrium real wage are given respectively by:

$$
L^{*}=Y^{*}
$$

7. Note that $Y$ is defined as the home country's nominal GDP deflated by $P$, i.e.

$$
Y=\frac{\sum_{i=1}^{n} p_{i} x_{i}}{P}
$$

The similar definition applies to $Y^{*}$.

8. Since $M=n p_{i} x_{i}=W L+\pi$, where $\pi$ is the nominal profit earned by home monopolists and $n$ is exogenous under the no-entry assumption, (1) can be written as,

$$
U=\frac{M}{P}-L^{\beta}=\frac{W L}{P}+\frac{\pi}{P}-L^{\beta}
$$

Thus, using $\partial \pi / \partial L=0$, the first-order condition, $\partial U / \partial L=0$ implies (19). 


$$
\frac{W^{*}}{P^{*}}=\beta Y^{* \beta-1}
$$

From (18)-(21), the labor supply curve of each country is vertical as $\beta$ approaches infinity or horizontal as $\beta$ is close to one. In between, each country's aggregate employment (output) is correlated positively with its domestic real wage. Hence, in line with empirical evidence as well as earlier closed-economies models of monopolistic competition 〈e.g. Blanchard and Kiyotaki [1987]), real wage is pro-cyclical here in the model.

The model is static with capital immobile across countries, hence ruling out the possibility of international borrowing or lending, and hence making it impossible for aggregate expenditure to exceed aggregate output in each country. In terms of (4), (5) and (16), the solvency constraint $C=Y$ for the home country is reduced to:

$$
\frac{p_{i}}{P}=\left(\frac{n}{n+n^{*}}\right)^{1 /(\sigma-1)}\left[\frac{M+e M^{*}}{M}\right]^{1 /(\sigma-1)}
$$

Similarly, the foreign country's counterpart is written as:

$$
\frac{p_{j}^{*}}{P^{*}}=\left(\frac{n^{*}}{n+n^{*}}\right)^{1 /(\sigma-1)}\left[\frac{M+e M^{*}}{e M^{*}}\right]^{1 /(\sigma-1)}
$$

From (22) and (23), the world's overall money stock relative to home (foreign) money stock determines the relative price of a home product to home (foreign) aggregate price, given the elasticity of substitution between goods $(\sigma)$ and the numbers of home and foreign products. An important policy implication here is that: whether monetary policy can change a country's domestically-produced-product's relative price depends on whether it can change this country's national money stock relative to worldwide money stock. As implied by (22) and (23), such possibility is unclear without looking into exchange-rate movements. However, it is clear that: when $\sigma$ is infinitely large, the possibility of monetary policy to change relative prices is completely ruled out. Indeed, in this limiting case, it holds that $P=p_{i}=e p_{j}^{*}=$ $e P^{*}$. That is, if the present model of monopolistic competition is reduced to that of perfect competition, PPP holds not only at aggregate price levels, but at individual price levels as well. 


\section{Impact of Foreign Monetary Disturbances}

This section begins to examine the impact of a foreign monetary shock on the world economy. First, let us take total differentials of (the log of) (9) and (14)-(23):

$$
\begin{aligned}
& \hat{P}=\hat{e}+\hat{P}^{*} \\
& \hat{p}_{i}=\hat{W}, \quad i=1,2, \ldots, n \\
& \hat{p}_{j}^{*}=\hat{W}^{*}, \quad j=1,2, \ldots, n^{*} \\
& \hat{Y}=-(\sigma-1)\left(\hat{p}_{i}-\hat{P}\right)+\theta(\hat{M}-\hat{P})+(1-\theta)\left(\hat{e}+\hat{M}^{*}-\hat{P}\right) \\
& \hat{Y}^{*}=-(\sigma-1)\left(\hat{p}_{j}^{*}-\hat{P}^{*}\right)+\theta(\hat{M}-\hat{P})+(1-\theta)\left(\hat{e}+\hat{M}^{*}-\hat{P}\right) \\
& \hat{L}^{*} \hat{Y}^{\prime} \\
& \hat{W}^{*}-\hat{P}^{\prime}=(\beta-1) \hat{Y}^{*} \\
& \hat{L}^{*}=\hat{Y}^{*} \\
& \hat{W}^{*}-\hat{P}^{*}=(\beta-1) \hat{Y}^{*} \\
& \hat{p}_{i}-\hat{P}^{*}=\left(\frac{1-\theta}{\sigma-1}\right)\left(\hat{e}+\hat{M}^{*}-\hat{M}\right) \\
& \hat{p}_{j}^{*}-\hat{P}^{*}=-\left(\frac{\theta}{\sigma-1}\right)\left(\hat{e}^{*}+\hat{M}^{*}-\hat{M}\right)
\end{aligned}
$$

where $\hat{z}(=d z / z)$ is a percentage change in $z$ and $\left(9^{\prime}\right)$ is the differential form of (9) and the like; $\theta$ of $\left(16^{\prime}\right)$ and $\left(17^{\prime}\right)$ measures the home country's money stock relative to the world's total money stock and can be taken as an indicator of country size; Like $n$ and $n^{*}, M$ is exogenous, and thus changes in $M$ represent the only force that drives the two individual prices $p_{i}$ and $p_{j}^{*}$ as well as the other nine macroeconomic variables: $e, P, P^{*}, W, W, Y, Y^{*}, L$, and $L^{*}$.

$\left(9^{\prime}\right)$ represents PPP in relative form with changes in the exchange rate (e) reflecting the discrepancy between home and foreign inflation rates. 
$\left(14^{\prime}\right)$ and $\left(15^{\prime}\right)$ specify home and foreign monopolists' optimum price adjustments, respectively, where one-percent increase in nominal wages leads to one-percent increase in individual prices. $\left(16^{\prime}\right)$ states that the home country's output growth is equal to the percentage change in worldwide real money balances minus the percentage change (weighted by $\sigma-1$ ) in the relative price of home individual products; the latter relative-price effect is negative because an increase in $p_{i} / P$ reduces the world demand for each home product in accordance with (10). The similar relationships apply to the foreign country's output growth due to $\left(17^{\prime}\right)$.

In each country, aggregate output and aggregate employment move in the same direction and in the same rate in each country, as indicated by $\left(18^{\prime}\right)$ and $\left(20^{\prime}\right)$. From $\left(19^{\prime}\right)$ and $\left(21^{\prime}\right)$, by contrast, economic growth may contribute to a disproportionate rise in real wage, subject to the elasticity of marginal disutility of labor (B). Finally, $\left(22^{\prime}\right)$ and $\left(23^{\prime}\right)$ represent the conditions ensuring aggregate output equal to aggregate consumption in the home and foreign countries, respectively. There, it is implied that as the foreign money stock (in home currency) $e M^{*}$ grows faster than the domestic money stock $M$, an increase in individual prices must be above (below) the inflation rate at home (abroad), subject to $\theta$ and $\sigma^{9}$

Two cases will be considered in computing the impact of changes in $M$ : In the first case, price adjustments are free so that monopolists can always adjust their prices to optimum in accordance with $\left(14^{\prime}\right)$ and $\left(15^{\prime}\right)$. In the second case, however, price adjustments are costly so that keeping prices rigid in response to shocks can be privately efficient. ${ }^{10}$ In addition, by changing the degree of monopoly power $(\sigma)$, the two market structures - monopolistic competition and perfect competition - will be taken into account in each case.

9. This also suggests that as foreign money stock (in home currency) grows faster than domestic money stock, the foreign inflation rate is higher than the domestic inflation rate, while the rise of domestic individual products exceeds the rise of foreign individual products.

10. As shown by Mankiw [1985] and Akerlof and Yellen [1985], price rigidity can only incur a second order loss to monopolists when they fail to adjust their prices to optimum so that even small price adjustment costs (or so called "menu costs") may lead to price rigidity, which is consistent with agents' optimization behavior. 
To facilitate analysis, readers should note that as required by $\left(16^{\prime}\right),\left(17^{\prime}\right)$, $\left(22^{\prime}\right)$ and $\left(23^{\prime}\right)$, the key to generating non-neutrality of money lies in whether changing national money stock can alter worldwide real money balances and/or whether changing national money stock can alter the relative national money stock between countries. The former shifts outward or inward the demand curves for individual products, while the latter increases or decrease the quantity demand of individual products.

\section{A. Case 1: Price Adjustments are Free}

The solutions for case 1 with price flexibility can be obtained simply by solving $\left(9^{\prime}\right)$ and $\left(14^{\prime}\right)-\left(23^{\prime}\right)$ and are given below:

$$
\begin{aligned}
& \hat{e}=-\hat{M}^{*} \\
& \hat{Y}=\hat{L}=\hat{W}=\hat{P}=\hat{p}_{i}=0 \\
& \hat{Y}^{*}=\hat{L^{*}}=0 \\
& \hat{W}^{*}=\hat{P}^{*}=\hat{p}_{j}^{*}=\hat{M}^{*}
\end{aligned}
$$

In the first case, the flexible exchange rate $(e)$ can exactly offset the foreign monetary shock in that this shock is unable to change both worldwide real money balances and the relative national money stock. As indicated by (24), changes in $M^{*}$ lead e to change proportionally in the opposite direction. That is, one-percent decrease in $M^{*}$ causes one-percent appreciation of the foreign currency, hence leaving unchanged the (home-currency) foreign money stock $\left(e M^{*}\right)$ and hence keeping the worldwide money stock $\left(M+e M^{*}\right)$ and relative national money stock fixed at the original levels. As a result, the flexible exchange rate insulates the home country perfectly from the shock as indicated by (25): neither the nominal side nor the real side is seen to be perturbed. The only impact of the shock that remains is that all foreign nominal variables $\left(W^{*}, P^{*}, p_{j}^{*}\right)$ vary proportionally with $M^{*}$, leaving unchanged the foreign country's aggregate output (employment) and real wage. Note that the scenario for the first case is independent of both country size (measured by $\theta$ ) and whether the goods market exhibits monopolistic competition (i.e. $\sigma$ is finite and above one) or perfect competition (i.e. $\sigma$ 
is infinitely large).

\section{B. Case 2: Price Adjustments are Costly}

In the second case, price adjustment costs prevent monopolists adjusting their prices to optimum. It should be noticed that although the prices of products are rigid in home currency, they are flexible in foreign currency due to exchange rate fluctuations. This asymmetric case results from the assumption of home and foreign markets being assumed to be integrated rather than segmented. Thus, the prices home firms receive from home and foreign markets are the same in terms of home currency - i.e. changes in the exchange rate is fully passed through to the prices of products sold abroad. It may be interesting to analyze the case with the home-currency price of good $x$ fixed in the home market and the foreign-currency price of the same good fixed in the foreign market as well <i.e. the case with pricing to market in the terminology of Krugman [1987]). To do so, however, we must abandon up the integrated-market assumption and let home and foreign markets be segmented, which is beyond the scope of the present study.

To compute the impact of a foreign monetary shock for the second case, one should suppress the two price rules $\left(14^{\prime}\right)$ and $\left(15^{\prime}\right)$ and impose the conditions of price rigidities for individual products $\hat{p}_{i}=\hat{p}_{j}^{*}=0 .{ }^{11}$ The solutions for the second case are given by (28)-(34):

$$
\begin{aligned}
& \hat{e}=-\left(\frac{1}{\sigma}\right) \hat{M}^{*} \\
& \hat{Y}=\hat{L}=\left(\frac{1-\theta}{\sigma}\right) \hat{M}^{*} \\
& \hat{W}-\hat{P}=(\beta-1)\left(\frac{1-\theta}{\sigma}\right) \hat{M}^{*} \\
& \hat{P}=-\left(\frac{1-\theta}{\sigma}\right) \hat{M}^{*}
\end{aligned}
$$

11. In the open economies model, individual-prices rigidities do not lead to aggregateprice rigidity due to exchange-rate movements, as opposed to open-economies models 〈e.g. Blanchard and Kiyotaki [1987]〉. 


$$
\begin{aligned}
& \hat{Y}^{*}=\hat{L}^{*}=\left(\frac{\sigma-\theta}{\sigma}\right) \hat{M}^{*} \\
& \hat{W}^{*}-\hat{P}^{*}=(\beta-1)\left(\frac{\sigma-\theta}{\sigma}\right) M^{*} \\
& \hat{P}^{*}=\left(\frac{\theta}{\sigma}\right) \hat{M}^{*}
\end{aligned}
$$

Here in the second case, it is seen that the flexible exchange rate cannot insulate the home country from a foreign monetary shock. For instance, decreased foreign money supply $\left(M^{*}\right)$ not only reduces the foreign country's aggregate output (employment) and real wage [(32) and (33)], but also exacerbates the home country's counterparts [(29) and (30)]. Further, the greater the degree of monopoly power (and the larger the size of the foreign country $1-\theta$ ), the more significant the impact of the foreign shock on the two large economies. On the monetary side, a decrease in $M^{*}$ leads to the rise in e or depreciation of the home currency in terms of (28), as predicted by most traditional models of perfect competition. ${ }^{12}$ The home-currency depreciation therefore raises the (home-currency) prices of imported goods, causing inflation in the home country as indicated by (31). To the contrary, the depreciation reduces the (foreign-currency) prices of imported goods, causing deflation in the foreign country in which a contractionary monetary shock originates.

In contrast to the first case with perfect insulation, the second case highlights the phenomenon that market imperfections plus price rigidities of individual products can fail the flexible exchange rate to protect a country from a foreign monetary disturbance. Insulation may occur to the second

12. Yet, in contrast to conventional sticky-price models $\langle$ e.g. Dornbusch [1976] $\rangle$, the model does not generate exchange-rate "overshooting" or "undershooting." This is because in the present model all markets clear instantaneously and individual monopolists keep their prices rigid all the time. Put it another way, say, in Dornbusch [1976], price rigidity is along with a disequilibrium in the goods market so that price will move to clear the market in the long run, but in the current context, price rigidity can be an equilibrium as in recent menu-costs models $\langle e . g$. Blanchard and Kiyotaki [1987]). 
case, but only when a becomes infinitely large - i.e. the degree of monopoly power decreases to zero or monopolistic competition degenerates into perfect competition. Otherwise, when monopolists cannot freely adjust their prices to optimum, monetary disturbances tend to transmit macroeconomic fluctuations abroad under flexible rates. Thus, the market mechanism that is responsible for the failure of the exchange rate to achieve insulation is in contrast to the literature based on perfect competition. ${ }^{13}$

In this study, as mentioned earlier, whether insulation can be achieved hinges on the interaction between changes in the home country's domestic relative price $\left(p_{i}, / P\right)$ and changes in worldwide real money balances $(M / P$ $+e M^{*} / P$ ) according to (16) or $\left(16^{\prime}\right)$. The literature ignores this interaction, however. When a foreign monetary shock is present, by using (16), (28) and (31), the resulting worldwide-real-money-balances effect on home aggregate output is given by:

$$
\theta(\hat{M}-\hat{P})+(1-\theta)\left(\hat{e}+\hat{M}^{*}-\hat{P}\right)=(1-\theta) \hat{M}^{*}
$$

while the relative-price effect on home aggregate output is given by:

$$
(1-\sigma)\left(\hat{p}_{i}-\hat{P}\right)=-\left(\frac{\sigma-1}{\sigma}\right)(1-\theta) \hat{M}^{*}
$$

The above two effects highlights the importance of market imperfection characterized by $(\sigma-1) / \sigma$, which is less than unity. Insulation can occur only if the two effects are offset each other. However, as monopolistic competition is present, the worldwide-real-money-balances effect (35) is seen to always outweigh the relative-price effect (36), thereby ruling out the possibility of insulation. Can the relative-price effect exactly offset the real-balances effect? Yes, but the premise is that monopolistic competition is reduced to perfect competition with a approaching infinity or $(\sigma-1) / \sigma$ getting close to unity.

13. In Artus and Young [1979], Mussa [1979], Dornbusch [1983] and Marston [1985], for example, flexible rates are generally unlikely to insulate the economy from foreign monetary shocks. The possible transmission channels they found include the foreign aggregate price level, the terms of trade and the real interest rate. In this study, the latter two channels are absent because PPP holds at aggregate price levels and because interest rates are suppressed by assumption. 


\section{Concluding Remarks}

This study has examined whether under a flexible-rate system the exchange rate can insulate a large economy from a monetary shock originating in another large economy. Its main findings have been summarized in Section I. An important policy issue emerges from the study is that: Can international policy coordination work to help exchange rates to mitigate the destabilizing effects of monetary or real disturbances in the context where monopolists' price adjustments are subject to the so called menu costs? According to the preliminary results of this study, any type of policy coordination must be able to reduce the gap between the two opposing effects on aggregate output: relative-price effect and worldwide real-moneybalances effect. Otherwise, foreign shocks can exacerbate output and employment fluctuations at home. The interaction between the two opposing forces is absent in the literature based on perfect competition. An extension of the present study to address this fine-tuning issue can enrich our understanding of the role of market imperfection in international macroeconomics.

\section{References}

Akerlof, G. and Yellen, J. [1985], "Can Small Deviations from Rationality Make Significant Difference to Economic Equilibria?” American Economic Review 75; pp. 708-21.

Artus, J. R. and Young, J. H. [1979], "Fixed and Flexible Exchange Rates: A Renewal of the Debate," International Monetary Fund Staff Papers 26; pp. 654-98.

Blanchard, Olivier J. and Kiyotaki, Nobuhiro [1987], "Monopolistic Competition and the effects of Aggregate Demand," American Economic Review 77; pp. 647-66.

Dornbusch, R. [1983], "Flexible Exchange Rates and Interdependence," International Monetary Fund Staff Papers 30; pp. 3-30.

Friedman, M. [1953], "The Case for Flexible Exchange Rates", in: M. Friedman, Essays in Positive Economics (University of Chicago Press, Chicago); pp. 157-203. 
Johnson, H.G. [1972], "The Case for Flexible Exchange Rates, in: H.G. Johnson, Further Essays in Monetary Economics (Allen and Unwin, London); pp. 198-222.

Krugman, Paul [1987], "Pricing to Market When the Exchange Rate Changes," in Real-Financial Linkages among Open Economies, ed., Sven W. Arndt and J. David Richardson (Cambridge: MIT press); pp. 49-70.

Lucas, R.E. [1973], "Some International Evidence on Output-Inflation Tradeoffs," American Economic Review, 63: pp. 326-34.

Mankiw, N. George [1985], "A Small Menu Costs and Large Business Cycles: A Macroeconomic Model of Monopoly," Quarterly Journal of Economics 100; pp. 529-39.

Marston, R.C. [1982], "Wages, Relative Prices and the Choice between Fixed and Flexible Exchange Rates," Canadian Journal of Economics, 15; pp. 171-86.

Marston, R.C. [1985], "Stabilization Policies in Open Economies," in: R.W. Jones and P.B. Kenen, ed., Handbook of International Economics (North-Holland, Amsterdam); pp. 859-916.

Meade, J.E. [1955], "The Case for Variable Exchange Rates," Three Banks Review, 27; pp. 3-28.

Mussa, M. [1979], "Macroeconomic Interdependence and the Exchange Rate Regime," in: R. Dornbusch and J. Frenkel, eds., International Economic Policy: Theory and Evidence (The Johns Hopkins University Press, Baltimore, MD).

Mussa, M. [1989], "Monopolistic Competition as a Foundation for Keynesian Macroeconomic Models," Quarterly Journal of Economics; pp. 73752.

Rotemberg, J.J. [1987], “The New Keynesian Microfoundations”, in: Stanley Fisher, eds, NBER Macroeconomics Annual 1987 (The MIT Press, Cambridge, Massachusetts and London England); pp. 69-104.

Saidi, N.H. [1980], "Fluctuating Exchange Rates and the International Transmission of Economic Disturbances," Journal of Money, Credit and Banking, 12; pp. 575-91. 